\title{
Climate justice and the ETOs
}

Sara L. Seck

\section{Introduction}

The aim of the Maastricht Principles on the Extraterritorial Obligations of States in the area of Economic, Social, and Cultural Rights (Maastricht Principles) has been described as to "clarify extraterritorial obligations of states' (ETOs) on the basis of existing international law, rather than to 'establish new elements of human rights law' (Greenpeace and CIEL 2014, p. 5). Two key questions arise from this ambition in the context of climate crisis and the quest for climate justice. First, can the Maastricht Principles be said to have contributed to a clarification of the law so as to assist in conceptualizing the legal obligations of states and other actors to prevent and remedy human rights harms arising from anthropogenic climate change? Secondly, are new elements of human rights law necessary to address the complexity of obligation in the context of climate crisis that go beyond the ETOs?

This chapter will consider both questions in turn. I will first consider some key conceptual issues of relevance to both the ETOs and the quest for climate justice. Second, with reference to several examples, I will illustrate how the concept of extraterritoriality may create confusion rather than clarity, especially in the climate context. I will then explore whether this confusion may be overcome if attention is paid to the precise nature of the relationships at issue to which obligations attach, rather than reinforcing the bright line of politically defined territorial boundaries. In conclusion, I will consider the implications of the right to a safe, clean, healthy, and sustainable environment, including a safe climate system, for ETOs and climate justice.

\section{Conceptual issues}

The key sources of international law relevant to the climate crisis are found within the international climate regime, including the 1992 United Nations Framework Convention on Climate Change (UNFCCC) and the 2015 Paris Agreement. Obligations of states under the climate regime are often classified as relating to mitigation or adaptation. Mitigation refers to efforts to reduce greenhouse gas (GHGs) emissions as well as efforts to enhance carbon sinks (UNFCCC (n.d.a)). There are many ways to reduce GHGs, including through decreased use of fossil fuels or by expanding forests to remove GHGs from the atmosphere. Yet, while mitigation of GHGs 
is clearly essential to reduce climate harms, and so has a positive impact on the enjoyment of human rights, the development of new green energy projects to replace reliance upon fossil fuels often lead to violations of human rights if undertaken without regard to the rights of local and Indigenous communities, among others (BHRRC 2020). Similarly, the expansion of forest carbon stocks in developing countries as encouraged under the climate regime's REDD-plus has also been associated with violations of the rights of local and Indigenous communities (FOEI 2017). Moreover, as the climate regime encourages both the creation of offsets and the trading of carbon credits, the spatial dimensions of climate mitigation become blurred: from a human rights perspective, how are we to understand the human rights responsibilities of a state that fails to reduce its own emissions (by failing to reduce reliance upon fossil fuels, for example) yet purchases carbon offsets from a developing state (where the forest carbon sink is being developed on lands from which a local community has been forcibly displaced)?

This story is further complicated by the importance of common but differentiated responsibilities and respective capabilities (CBDR) which remains fundamental to the climate regime including under the Paris Agreement even as it has evolved to embrace a pragmatic approach (Galvao Ferreira 2018). The original justice-based version of CBDR under the UNFCCC and Kyoto Protocol informed the central obligations of states to reduce GHG emissions, distinguishing clearly between the obligations of developed and developing states, with the obligation to 'go first' placed on developed states due to both greater capabilities and historic responsibilities (Galvao Ferreira 2018, pp. 34-35). However, this version of differentiation was seen as compromising universal participation by some developed countries who then expressed objection to the exemption of emerging economies with significant emissions from emissions reduction obligations (Galvao Ferreira 2018, p. 36). As a result, the Paris Agreement refers to 'common but differentiated responsibilities and capabilities, in light of different national circumstances' and all state parties are now required to 'formulate, communicate, and update their nationally determined contributions' with regard to emissions reductions (Galvao Ferreira 2018, pp. 38-40). Yet, from a human rights perspective, it is not obvious how to reconcile the Paris Agreement's voluntary approach to emissions reduction targets (mitigation), with the obligations of states under international human rights law to reduce GHG emissions 'within the shortest possible time frame both nationally and through international cooperation and assistance' with the move to zero carbon emissions by developed states to ideally happen by 2030 (Khalfan and Liguori 2020, p. 15). This is especially so if attention is paid, as it should be, to responsibility for historic emissions, and related issues of climate justice.

Adaptation, on the other hand, may be defined as 'adjustments in ecological, social, or economic systems in response to actual or expected climatic stimuli and their effects or impacts' (UNFCCC (n.d.b)). Again, there is no single adaptation response; rather adaptation actions can range from early warning systems to flood defences to drought-resistant crops, and much more. Adaptation measures may successfully reduce climate harms and so have a positive impact on the enjoyment of human rights of some, yet adaptation initiatives may at the same time be implemented in a manner that disregards the human rights of others.

While loss and damage initially emerged as a component of the Cancun Adaptation Framework, it has developed as a distinct area since its incorporation into the Paris Agreement (Doelle and Seck 2020, p. 670). Loss and damage are defined in the literature as comprised of two categories of harm: permanent (an irrecoverable loss); and reparable (recoverable damage) (Doelle and Seck 2020, p. 669). Whether or not loss and damage occur is dependent upon both mitigation and adaptation: some loss and damage impact today may have been 'avoided' by mitigation efforts, while future loss and damage may be 'avoidable' should mitigation be enhanced or adaptation undertaken. Where future efforts cannot prevent loss and damage, however, it is 
'unavoidable' (Doelle and Seck 2020, p. 669). From a human rights perspective, are violations of human rights arising from climate loss and damage to be understood as resulting from the failure of a state (or a non-state actor) to reduce greenhouse gas emissions (or purchase equivalent offsets), or from the failure of a state (perhaps a different one) to implement effective adaptation measures, or both? There is then the reality that climate change is the result of cumulative emissions, raising complex but not insurmountable questions of allocation and attribution (Heede 2014).

To understand the human rights implications of climate changes requires moving beyond the climate regime, given the sole reference to human rights is found in the preamble of the Paris Agreement. Sources of international human rights law are increasingly grappling with climate change (United Nations General Assembly (UNGA) 2019, pp. 15-17), including the July 2019 Safe Climate report by David Boyd, the Special Rapporteur on the issue of human rights obligations relating to the enjoyment of a safe, clean, healthy, and sustainable environment (UNGA 2019). The Safe Climate report first canvasses the devastating impact of the climate emergency globally on the enjoyment of human rights, then clarifies state obligations and business responsibilities, concluding with practical recommendations on what is required to protect a safe climate. Among the rights identified by Boyd that are currently 'threatened and violated' by climate change 'are the rights to life, health, food, water and sanitation, a healthy environment, an adequate standard of living, housing, property, self-determination, development and culture', as well as the rights of the child and others who are especially vulnerable (UNGA 2019, p. 10). Importantly, while those who have contributed most to the problem have the greatest responsibility to solve it, and have also 'reaped immense economic benefits', people living in poverty have contributed minimally to the problem, yet 'lack the resources to protect themselves or to adapt to the changes' (UNGA 2019, p. 10). Thus, as documented by the Special Rapporteur on extreme poverty and human rights, 'the adverse impacts of climate change disproportionately affect people living in poverty', and, the world faces 'a future of climate apartheid, where the wealthy pay to shield themselves from the worst impacts of climate change while the poor suffer immensely' (UNGA 2019, p. 10). However, a rights-based approach to climate change has the potential to contribute to solutions by highlighting 'principles of universality and nondiscrimination, emphasizing that rights are guaranteed for all persons, including vulnerable groups' (UNGA 2019, p. 10).

What might this mean for state obligations, and in particular our understanding of their 'reach'? And what of business responsibilities? The Safe Climate report does not refer to the ETOs or 'extraterritoriality', rather framing state obligations in accordance with the 2018 Framework Principles on Human Rights and the Environment put forward by the former Special Rapporteur John Knox (United Nations Human Rights Council (UNHRC) 2018), as falling into three categories: 'procedural, substantive, and special obligations towards those in vulnerable situations', a framework that 'can be operationalized in the context of climate change in order to respect, protect and fulfil human rights' (UNGA 2019, p. 17). With regard to substantive obligations, Boyd clarifies:

States must not violate the right to a safe climate through their own actions; must protect that right from being violated by third parties, especially businesses; and must establish, implement and enforce laws, policies and programmes to fulfil that right. States also must avoid discrimination and retrogressive measures. These principles govern all climate actions, including obligations related to mitigation, adaptation, finance, and loss and damage.

(UNGA 2019, p. 18) 
These human rights obligations are 'reinforced by international environmental law', as according to the 'do no harm' principle, 'States are obliged to ensure that polluting activities within their jurisdiction or control do not cause serious harm to the environment or peoples of other States or to areas beyond the limits of national jurisdiction' (UNGA 2019, p. 18). Consequently: "Given the foreseeability of increasing climate impacts, this well-established "no harm" rule of customary international law is being violated as a result of greenhouse gas emissions, which, regardless of where they are emitted, are contributing, cumulatively, to adverse effects in other States, including small island developing States' (UNGA 2019, p. 18). This framing accords with the conceptualization of climate change as a common concern for all states, in keeping with the UNFCCC, and one that is a shared responsibility and requires international cooperation (Seck 2011a, pp. 180-181). Indeed, according to the Safe Climate report, the 'obligation to cooperate to achieve a low-carbon, climate resilient and sustainable future' extends to the sharing of information, transfer of climate-friendly technologies from wealthy to poorer states, the honouring of international commitments, and the need to ensure 'fair, legal and durable solutions for migrants and displaced persons' (UNGA 2019, p. 19). With regard to finance, Boyd clarifies the importance of funds to low-income countries being in the form of grants rather than loans: 'It violates basic principles of justice to force poor countries to pay for the costs of responding to climate change when wealthy countries caused the problem' (UNGA 2019, p. 19). He concludes the assessment of state obligations with reference to the work of the Committee on Economic, Social, and Cultural Rights who warned states in 2018 that:

a failure to prevent foreseeable human rights harms caused by climate change, or a failure to mobilize the maximum available resources in an effort to do so, could constitute a breach of their obligation to respect, protect and fulfil all human rights for all. States must, therefore, dedicate the maximum available financial and material resources to shift to renewable energy, clean transport and agroecological farming; halt and reverse deforestation and soil deterioration; and increase adaptive capacity, especially in vulnerable and marginalized communities.

(UNGA 2019, p. 19)

Another crucial clarification in the Safe Climate report is the responsibility of businesses, in line with the 2011 UN Guiding Principles on Business and Human Rights (UNGA 2019, p. 19). Accordingly, businesses 'must adopt human rights policies, conduct human rights due diligence, remedy human rights violations for which they are directly responsible and work to influence other actors to respect human rights where relationships of leverage exist' (UNGA 2019, p. 19). Specifically, businesses have five main responsibilities in relation to climate change:

to reduce greenhouse gas emissions from their own activities and their subsidiaries; reduce greenhouse gas emissions from their products and services; minimize greenhouse gas emissions from their suppliers; publicly disclose their emissions, climate vulnerability and the risk of stranded assets; and ensure that people affected by business-related human rights violations have access to effective remedies. In addition, businesses should support, rather than oppose, public policies intended to effectively address climate change.

(UNGA 2019, pp. 19-20)

The identification of duty-bearers beyond states in the Safe Climate report is important given the complexity of climate change, and the prominence of attribution science that measures the greenhouse gas emissions from carbon major companies (whether private or state-owned) since 
the industrial revolution (Heede 2014). These studies serve as the foundation for an increasing number of climate litigation cases against fossil fuel companies, arguably an important piece of the quest for climate justice and accountability (Ganguly, Setzer and Heyvaert 2018).

\section{ETOs and climate justice: Clarity or confusion?}

While the discussion of state obligations in the human rights and climate change space may not refer explicitly to the Maastricht Principles or the concept of extraterritoriality, it is arguable that these are implicit in the way in which the human rights obligations of states are conceptualized in clarifications such as the 2019 Safe Climate Report. Nevertheless, it is important to ponder whether the lack of embrace of ETOs' language is incidental or deliberate, and, importantly, whether it might matter or not. In this part I will first briefly consider the relevance of ETOs to human rights and climate change and then offer a few examples which suggest that the language of extraterritoriality itself may create confusion rather than add clarity when contemplating climate obligations, and so is perhaps best avoided. Instead, I will argue that relational language that intentionally speaks to the nature of the relationship to which the obligation attaches hold more promise for the realization of climate justice and accountability.

How might ETOs contribute to solutions to climate change and assist those most vulnerable to climate harms in seeking climate justice? According to a report on the Maastricht Principles and climate change authored by Greenpeace and CIEL, Maastricht Principle 13's 'Obligation to avoid causing harm' is directly relevant to transboundary and global environmental issues such as climate change, by confirming the extraterritorial reach of state obligations to refrain from actions or omissions that risk the nullification or impairment of the enjoyment of social, economic, and cultural rights (Greenpeace and CIEL 2014, p. 6). This obligation is engaged when the harm is foreseeable and may not be justified on the basis of a lack of certainty, in keeping with international environmental law's precautionary principle. Maastricht Principles 28 and 29, read in relation to Principles 30-35, 'reiterate the obligations of States to take deliberate, concrete and targeted steps, separately and jointly through international cooperation, to create an international enabling environment conducive to the universal fulfilment of ESCRs, including in matters of environmental protection' (Greenpeace and CIEL 2014, p. 6). In addition, Maastricht Principle 17 provides that states 'must elaborate, interpret and apply relevant international agreements and standards in a manner consistent with their human rights obligations, including those pertaining to environmental protection', while Maastricht Principles 23-27 elaborate the state 'duty to regulate to ensure that non-State actors do not nullify or impair the enjoyment of economic, social and cultural rights' whether by 'administrative, legislative, investigative, or adjudicative measures' (Greenpeace and CIEL, p. 6). In sum, the report claims that the 'Maastricht Principles provide an excellent tool for holding governments accountable for extraterritorial violations of human rights on the basis of their existing obligations under international law' including those that require them to 'regulate and hold private corporations accountable for human rights violations resulting from their activities abroad and provide remedies to victims' as well as the 'use [of] their influence in international policy fora to create an enabling environment for the realization of human rights, including those relating to the right to a healthy environment, and cooperate internationally to mitigate the negative effects of eco-destruction and climate change' (Greenpeace and CIEL 2014, p. 10).

In practice, however, it is not so easy to apply the concept of extraterritoriality to the climate context as will be shown below with reference to a few examples. Indeed, as I have argued elsewhere, it may be important to move beyond the language of extraterritoriality (the 'e-word') in a time of climate and planetary crisis, so as to consciously avoid reinforcing the mythical image 
of the bounded autonomous state which flows from the unconscious adoption of the image of the bounded autonomous individual (liberal man) as a model for the sovereign nation state (Seck 2019a). The key point is that (in my own words) language which 'reinforces a vision of the territorially bounded sovereign state as an independent, autonomous being [...] in a time of global ecological crisis, is not only unhelpful, but undermines the critical importance of building mutually supportive relationships that acknowledge the reality of our ecological interdependence' (Seck 2019a, pp. 57-58). It is true that Maastricht Principle 8 defines ETOs as encompassing both 'obligations relating to acts and omissions of a State, within or beyond its territory, that have effects on the enjoyment of human rights outside of that State's territory' and 'obligations of a global character that are set out in the Charter of the United Nations and human rights instruments to take action, separately, and jointly through international cooperation, to realize human rights universally'. Clearly, the Maastricht ETOs embrace a vision of ETOs that includes support for global relationship building. Yet, I worry that conceptualizing this as 'extraterritorial' is nevertheless problematic.

To explain, the 'e-word' is associated under principles of public international law with the illicit exercise of jurisdiction beyond the foundational basis of state jurisdiction: territoriality. The problem rests in part with the fact that 'extra'-territorial, as the binary opposite of 'territorial', allows for no nuance. So, while the ETOs aim to clarify the extraterritorial nature of state obligations in the context of the primary rules of international human rights law, as distinct from the permissive exercise of jurisdiction under rules of public international law, the reality is that many states express discomfort with the exercise of state jurisdiction in the first place, often claiming concern that they may infringe the sovereignty of other states (Seck 2008). This discomfort may equally be attributable to the state's failure to acknowledge that certain state actions already have implications beyond borders to which human rights obligations must attach (Seck 2011b). If it is commonly believed that it may be impermissible to even exercise jurisdiction in a particular context, how can one then have a serious conversation about obligations to do so?

Legitimate exercise of jurisdiction from a public international law perspective is based on territoriality jurisdiction, or nationality (active personality) jurisdiction, with other more contested possibilities including passive personality jurisdiction, effects (a version of territoriality), as well as universal jurisdiction in limited instances. There is no public international law doctrine that legitimizes the exercise of extraterritorial jurisdiction per se, and so it is crucial to refer back to some other basis to legitimate the reach of state law. Moreover, the exercise of state jurisdiction could be prescriptive (legislative), adjudicative (judicial), investigative, or in relation to enforcement, and the legitimacy or illicitness of the jurisdictional reach will differ with each context. Finally, rules of private international law are crucial in determining how a court understands its role, and whether or not the case before it is one that it should hear, and to which it should apply forum or foreign law, or whether it is a case best heard in a foreign jurisdiction with a closer connection, where a foreign court may then choose to apply its own law as the most closely connected, or the law of another forum. In short, judicial analysis of legitimate exercise of jurisdiction can be complex. My concern is that the Maastricht Principles, which invoke the language of 'extraterritoriality', albeit in the context of state obligations under international human rights law, may inadvertently reinforce the muddiness of waters that might otherwise be at least slightly clearer.

As an example, in the corporate accountability context, the Kiobel litigation under the US Alien Tort Statute (ATS) is notorious for having led to a limitation in the potential for ATS litigation against multinational corporations (United States Supreme Court (USSC) 2013). The United States Supreme Court based its decision on the presumption against extraterritoriality, 
a doctrine that provides that unless a statute explicitly indicates that it applies beyond the realm, it is to be construed in a territorially bounded manner. On the facts the connection between the multinational enterprise and the US was less strong than it would have been had the head office of the enterprise at issue been located in the US. Nevertheless, it did indeed carry out business in the US, and the sweeping scope of the majority's decision made no distinction in any case. Conceptualizing the relationships at issue as extraterritorial undermines the ability to draw attention to the transnational nature of economic relationships, which would enable a more nuanced analysis of responsibility flowing from existing interdependence and aligning with calls for transnational access to justice (Seck 2013a). A different point is that responsibilities of non-state actors under international law, including transnational businesses, are increasingly captured by reference to the umbrella term of transnational law, arguably another version of relational responsibility (Seck 2013b). The phrase transnational obligations would therefore seem more appropriate; after all, we do not call them extraterritorial corporations or extraterritorial enterprises.

The Kiobel litigation has unfortunately inspired US courts charged with litigation brought by cities against fossil fuel companies in the climate context to similarly invoke the presumption against extraterritoriality even in cases where there is no statute to be interpreted, with the allegations resting on state nuisance law (Rudyan 2019). Much litigation later, the litigation continues over whether the cases should be heard in federal or state courts with outstanding issues of personal jurisdiction over foreign corporations (United States Court of Appeals for the Ninth Circuit (n.d.), summary). Nevertheless, there is no question that the harms alleged are harms in the United States - indeed, harms to specific cities - a solid territorial connection that is quite distinct from the facts of Kiobel.

Another example is the carbon majors case before the Philippines Human Rights Commission (Greenpeace Philippines 2015). The petitioners framed the problem with reference to the Maastricht Principles on ETOs. Yet, clearly harm to Filipinos in the Philippines provides a clear territorial nexus from which to justify an investigation by the Philippines Human Rights Commission, even if multiple defendant corporations locate their head offices or operate their businesses outside the Philippines, or if the emissions responsible for the harm originate from all over the world (Seck 2019a, p. 56). The undeniable territoriality of the climate harms, whether to people or the environment physically located in the Philippines, establishes a real and substantial connection between the allegations and the territory, sufficient to establish subject matter jurisdiction even if each individual defendant might contest the exercise of jurisdiction over them by the Commission by claiming a lack of personal jurisdiction as indeed many did (Seck 2019a; Seck 2017). At the end of the day, the Commission continued its public inquiry and the final outcome has not yet been released. However, it is unclear whether it was helpful or possibly confusing to raise the ETOs and so indirectly the e-word in relation to this investigation. Clearly, a domestic human rights commission should - must - hear claims relating to local human rights harms, even if some or most of those alleged to have caused the harms are not based within the forum territory. The effectiveness of such an inquiry at the end of the day is quite a different question from the obligation to hold the inquiry in the first place. For example, while Ecuadorean courts in the notorious litigation over oil pollution in the Amazon issued a multibillion-dollar judgment against Chevron and in favour of the plaintiffs, seeking enforcement of this judgment in foreign courts where corporate assets are held has proven to be extremely challenging (Seck 2013b, p. 193).

Similar curious reference to extraterritoriality is found in other climate contexts. For example, the Committee on the Elimination of Discrimination Against Women released a periodic report on Norway in which it stated that Norway should (as I have described previously): 
review its policies on energy and climate change so as to ensure its policy on oil and gas extraction "takes into account the disproportionate negative impacts of climate change" on the rights of women, especially those in poverty who are "more reliant on natural resources for their livelihoods"

(Seck 2019a, p. 56)

This statement is found in a section entitled: 'Extraterritorial state obligations'. Yet, the negative impacts of climate change on the human rights of women are also felt in Norway - perhaps most especially by members of the Indigenous Sámi (Prior and Heinämäki 2017). This is not to say that increased emissions arising from increased exploitation of fossil fuels will not have a disproportionate impact on the rights of women living in poverty outside of Norway; nevertheless, it is curious that the reference here is made only to women outside of Norway, and not to those within: Why not all poor women reliant upon natural resources for their livelihoods irrespective of where in the world they live? What does framing this as an issue of ETOs add?

A possible answer might be that where impacts outside the state are more severe, these could bolster arguments to stop harmful activities before they have begun. Yet, commentators reflecting on the People v. Artic Oil case before the Norwegian Supreme Court have also queried the usefulness of the concept of 'extraterritoriality' (Duffy and Maxwell 2020). This case was brought by a coalition of environmental groups who claimed that the Norwegian government's issuance of a block of oil and gas licenses to explore for undeveloped fossil fuel deposits in the Barents Sea violated the Norwegian Constitution's right to a healthy environment, as well as Articles 2 and 8 of the ECHR, by failing 'to exercise due diligence to protect against the human rights implications of climate change' (Duffy and Maxwell 2020). According to Duffy and Maxwell, the Norwegian Court of Appeal's decision, finding against the plaintiffs, held that Norway's jurisdiction was limited to 'the risks of harm within Norway, inter alia, as the state is not responsible for impact on rights beyond its borders' (Duffy and Maxwell 2020). The case raised geographically complex facts, as the allegations were that Norway should be responsible for all GHG emissions arising from the exploration, extraction, and production within Norway of the fossil fuel resource, as well as the GHG emissions that would arise from combustion of these resources once exported outside of Norway. Yet, Norway and every other country in the world would be affected by the GHG emissions as each stage of release would contribute to the global climate change problem. Ultimately, according to Duffy and Maxwell, the Court of Appeal held that:

the global consequences of climate change were beyond the scope of the state's obligations under the ECHR, such that it could only assess the projected impacts of climate change in Norway (which it found to be "serious", but "more limited and of a different nature than the global effects", even at warming of $4.5^{\circ} \mathrm{C}$ ). Second, it found that there was no "real and immediate" risk of harm to life of persons within Norway, and no "direct and immediate link" between the impugned decision and resulting harm.

(Duffy and Maxwell 2020)

While Duffy and Maxwell initially describe this outcome as being about 'the extent to which the Convention applies "extraterritorially", they subsequently query whether this is the right framing:

That said, the Norwegian case also prompts a more preliminary question: is the case really "extra-territorial" at all? The claimants allege that it is not. The impugned conduct - the 
grant of government licenses - takes place within the state, in respect of exploration and drilling that would also take place on Norwegian territory, but where its effects would be inextricably internal and external. The ECtHR's "exceptional"” extra-territorial jurisprudence, by contrast, developed in situations where state agents operated beyond its borders and allegedly violated the rights of persons also situated outside the state's territory. One could query whether this makes a difference, given the wording of the jurisdiction clause and its focus on persons within the state's jurisdiction? Brief regard to ECtHR practice suggests, however, that it may.

(Duffy and Maxwell 2020)

These examples raise the question of whether there is a systemic, conceptual problem with human rights obligations beyond borders (ETOs) per se or only with respect to their mobilization and interpretation in the climate context. As noted above, I have concerns about the use of the word 'extraterritorial' to describe state obligations in the transnational corporate accountability context, recommending instead that the description of the obligation reflect the nature of the relationship to which the obligation attaches. In the climate context, these relationships are often both geographically and structurally complex. For example, in the Philippines petition, the concern was over harms to people in the Philippines, and the responsibility of emitters primarily outside the Philippines including transnational enterprises and their home states. On the other hand, in the Norwegian Arctic Oil case, the concern was with preventing conduct in Norway (and subsequent conduct outside of Norway), so as to prevent harm both to those within and outside of Norway. Moreover, in the climate context, the problem is both that the global climate system is shared by everyone, and that the cause of the harm is cumulative GHG emissions from everywhere - yet those most vulnerable to harms are often those who have least contributed to the problem, and climate attribution science is increasingly able to clarify the percentage contribution to global GHG emissions of specific state and non-state carbon majors. The problem is best conceptualized as one of climate justice, which requires recognition of the deeply interconnected nature of earth systems and people everywhere, including transnational economic relationships, even as responsibilities and capabilities are differentiated.

\section{The right to a safe, clean, healthy, and sustainable environment - safe climate}

Having said all of this, the reality is that ETOs - at least as understood as transnational, transboundary, common concern, cross-border, or global climate harms - are most certainly relevant, and applicable to the climate change context. Indeed, Maastricht Principle 27 frames the obligation as one of cooperation: 'All States must cooperate to ensure non-state actors do not impair the enjoyment of economic, social and cultural rights of any person. This obligation includes measures to prevent human rights abuses by non-state actors, to hold them to account for any such abuses, and to ensure an effective remedy for those affected'. This is undeniably true in the climate context, yet remains elusive in practice.

According to a detailed analysis of state responsibility for human rights violations in the context of climate change by Ottavio Quirico (2018), the international recognition of a human right to a healthy environment could have implications for the analysis of both extraterritoriality and policy discretion in climate litigation. It is true that there are always external implications to recognition of internal human rights obligations in the climate cases examined by Quirico, as a 'merely internal duty to take adequate adaptation and mitigation policies against climate change' has 'beneficial extraterritorial effects' for 'citizens of other countries, because of the 
global common nature of the atmosphere' (Quirico 2018, pp. 196-197). While this is useful if the arguments are focused on mitigation and adaptation to climate change, the problem of remedy for diagonal human rights harms necessitates additional work. This could be accomplished with systemic integration of human rights and climate regimes through a general state duty to prevent climate change in line with the Paris Agreement's 1.5-degree threshold quantified in accordance with a fair share (Quirico 2018, pp. 209-210). If a sustainable environment (safe climate system) were conceptualized as both an erga omnes duty and right, this 'would contribute to overcoming the discrepancy between the territorial scope of application of human rights and the transboundary nature of GHG emissions' with 'the universal scope of the claim' also aligning with notions of intergenerational justice, and so protection of future generations (Quirico 2018, p. 211).

Substantive environmental rights are clearly receiving increased attention in regional human rights mechanisms, and through international initiatives pushing for recognition. Among notable developments is the Inter-American Court of Human Rights (IACtHR)'s Advisory Opinion on Environment and Human Rights, issued in response to a request from Colombia to clarify the scope of state responsibility under the American Convention on Human Rights with regard to environmental harm (IACtHR 2017). While the request may have been motivated by activities other than climate change, the resulting judgment clearly embraces the idea that states 'have a duty to prevent transboundary environmental damage that could impair the rights of persons outside their territory' on the basis of effective control over activities (Banda 2018), an idea sometimes described as invoking diagonal rights (FeriaTinta and Milnes 2018). Notably, while the English translation of the Advisory Opinion does use the language of extraterritoriality in its analysis, it avoids the term in its conclusions, where the court specifies that under the American Convention, the concept of jurisdiction 'encompasses any situation in which a State exercises effective control or authority over a person or persons, either within or outside its territory' (IACtHR 2017, para. 104(e)). 'States must ensure that their territory is not used in such a way as to cause significant damage to the environment of other States or of areas beyond the limits of their territory' (IACtHR 2017, para. 104(f)); and 'States are obliged to take all necessary measures to avoid activities implemented in their territory or under their control affecting the rights of persons within or outside their territory' (IACtHR 2017, para. 104(g)). The approach of the IACtHR is also endorsed by Duffy and Maxwell (2020), suggesting that it 'leads the way in firmly rejecting the idea that human rights obligations are inapplicable based on formalistic notions of territorial or personal control'.

Beyond the scope question, the Advisory Opinion is also noteworthy for having 'recognized the existence of an "autonomous" right to a healthy environment' under Article 26 of the American Convention, a right that arguably 'protects the environment per se' (Banda 2018). This opens the door to the justiciability of claims absent evidence of harm to humans, a development that reflects relational world views, as well as the importance of intergenerational justice. In this light, it is interesting to see how youth petitioners have framed their claims in a Communication to the Committee on the Rights of the Child (2019). While the petition was deliberately crafted to ensure that there was a petitioner who was either a national or resident of each respondent country, they nevertheless carefully state that 'all petitioners, however, are within the jurisdiction of each respondent because the petitioners are all victims of the foreseeable consequences of the carbon pollution knowingly emitted, permitted, or promoted by each respondent from within their respective territory' (CRC Communication 2019, para. 241). Moreover, the actions of each respondent are said to be 'causing and perpetuating the climate crisis and violate the petitioners' rights' (CRC Communication 2019, Part IX). 


\section{Conclusions}

This chapter has considered two key questions: first, can the Maastricht Principles be said to have contributed to a clarification of the law so as to assist in conceptualizing the legal obligations of states and other actors to prevent and remedy human rights harms arising from anthropogenic climate change? Secondly, are new elements of human rights law necessary to address the complexity of obligation in the context of climate crisis that go beyond the ETOs?

With regard to the first question, it is clear that invocation of the Maastricht Principles without careful consideration of whether or not the climate problem at issue is one that involves extraterritorial obligation has led to confusion rather than clarity. However, it is also evident, given the geographic and structural complexity of climate claims, that binary distinctions between territorial and extraterritorial obligations may not be terribly useful in any case. This concern may be somewhat mitigated by reference to obligations in relation to global harms combined with duties of international cooperation, and it is arguable that more explicit relational language such as invocation of obligations to prevent and remedy transboundary, cross-border, transnational, or common concern environmental human rights harms (depending on the context) may be preferable (Seck 2011a, pp. 163-181). Nevertheless, ultimately it is important to not lose sight of the climate justice dimensions at issue despite the failure of the international climate regime to explicitly acknowledge the responsibility and liability of historically high-emitting developed states for climate loss and damage even as experienced by the most vulnerable and least-responsible developing states.

An evolving question is whether new elements of human rights law are necessary to address the complexity of obligation in the context of the climate crisis, such as through explicit and universal recognition of a right to a safe climate system through recognition of a right to a safe, clean, healthy, and sustainable environment. A different but equally important question is whether what is necessary is a paradigm shift in terms of how the 'human' who is the holder of rights is understood: if all humans were conceptualized as ecologically embedded relational individuals, although differentially situated, as I have argued elsewhere (Seck 2019b; Seck 2021), then the same result could be reached without waiting for universal state recognition of a right that is in essence to not be subject to anthropogenic planetary destruction. Moreover, ecologically embedded relational individuals - which we all are - are found everywhere - from corporate boardrooms to investment advisors to politicians to climate refugees. While we all require a safe climate in order to thrive, those most vulnerable to climate harms are whose rights are already violated due to race, poverty, disability, age, gender, and/or indigeneity, among other identities. Transformative re-imagining of the 'human' with attention to difference may be a key part of the climate justice puzzle.

\section{References}

Banda, M.L. (2018) 'Inter-American Court of Human Rights' Advisory Opinion on the Environment and Human Rights', ASIL Insights 22(6) https://www.asil.org/insights/volume/22/issue/6/inter-american-court-human-rights-advisory-opinion-environment-and-human [accessed 12 January 2021].

Business \& Human Rights Resource Centre (BHRRC) (2020) 'Renewable Energy \& Human Rights Benchmark: Key Findings from the Wind \& Solar Sectors', https://media.business-humanrights.org/ media/documents/files/Renewable_Energy_Benchmark_Key_Findings_Report.pdf [accessed 12 January 2021].

Committee on Economic, Social, and Cultural Rights (CESCR) (2018) 'Climate change and the International Covenant on Economic, Social, and Cultural Rights', available at www.ohchr.org/en/NewsEvents/Pages/DisplayNews.aspx?NewsID=23691\&LangID=E [accessed 12 January 2021]. 
Communication to the Committee on the Rights of the Child (2019) in the case of Sacchi et al. $v$. Argentina, Brazil, France, Germany \& Turkey, available at https://childrenvsclimatecrisis.org/wp-content/ uploads/2019/09/2019.09.23-CRC-communication-Sacchi-et-al-v.-Argentina-et-al.pdf [accessed 12 January 2021].

Doelle, M. and Seck, S. (2020) 'Loss \& Damage From Climate Change: From Concept to Remedy?', Climate Policy 20(6), 669-680.

Duffy H. and Maxwell L. (2020) 'People v. Arctic Oil before the Supreme Court of Norway - What's at Stake for Human Rights Protection in the Climate Crisis?', EJIL Talk! Blog, 13 November 2020, https://www.ejiltalk.org/people-v-arctic-oil-before-supreme-court-of-norway-whats-at-stake-forhuman-rights-protection-in-the-climate-crisis/ [accessed 12 January 2021].

Feria-Tinta, M. and Milnes, S. (2018) 'The Rise of Environmental Law in International Dispute Resolution: Inter-American Court of Human Rights issues Landmark Advisory Opinion on Environment and Human Rights', EJIL:Talk! Blog, 26 February 2018, https://www.ejiltalk.org/the-rise-of-environmental-law-in-international-dispute-resolution-inter-american-court-of-human-rights-issues-landmarkadvisory-opinion-on-environment-and-human-rights/ [accessed 12 January 2021].

Friends of the Earth International (FOEI) (2017) 'REDD+ The Carbon Market and California-AcreChiapas Cooperation: Legalizing Mechanisms of Dispossession', https://www.foei.org/wp-content/ uploads/2018/01/REDD_The-carbon-market-and-the-California-Acre-Chiapas-cooperation.pdf [accessed 12 January 2021].

Galvao Ferreira, P. (2018) 'Differentiation in International Environmental Law: Has Pragmatism Displace Considerations of Justice' in Craik, N., Jefferies, C.S.G., Seck, S.L. and Stephens, T., (eds). Global Environmental Change and Innovation in International Law, Cambridge University Press.

Ganguly, G., Setzer, J., and Heyvaert, V. (2018) 'If at First You Don't Succeed: Suing Corporations for Climate Change', Oxford Journal of Legal Studies 38(4), 841-868.

Greenpeace and Center for International Environmental Law (CIEL) (2014) 'Extraterritorial Obligations in the Context of Eco-destruction and Climate Change', FIAN International for the ETO Consortium, https://www.fian.org/fileadmin/media/publications_2015/ETO_and_climate_change.pdf [accessed 12 January 2021].

Greenpeace Philippines (2015) 'Petition to the commission on human rights of the Philippines requesting for investigation of the responsibility of the carbon majors for human rights violations resulting from the impacts of climate change', available at https://www.greenpeace.org/static/planet4-philippinesstateless/2019/05/5a38951a-5a38951a-cc-hr-petition_public-version.pdf [accessed 12 January 2021]

Heede, R. (2014) 'Tracing Anthropogenic Carbon Dioxide and Methane Emissions to Fossil Fuel and Cement Producers 1854-2010', Climatic Change 122, 229-241.

Inter-American Court of Human Rights (IACtHR) (2017) The Environment and Human Rights (State Obligations in Relation to the Environment in the Context of the Protection and Guarantee of the Rights to Life and to Personal Integrity - Interpretation and Scope of Articles 4(1) and 5(1) of the American Convention on Human Rights), Advisory Opinion OC-23/18, Series A no. 23, English translation available at https://www.corteidh.or.cr/docs/opiniones/seriea_23_ing.pdf.

Khalfan, A. and Liguori, C. (2020) 'Amnesty's approach to climate change and human rights' in Ismangil, D., van der Schaaf, K. and van Troost, L. (eds). Climate Change, Justice, and Human Rights, Amnesty International Netherlands.

Oslo District Court, Borgarting Court of Appeal and Norwegian Supreme Court (n.d.) Greenpeace Nordic Ass'n v. Ministry of Petroleum and Energy, summary, Climate Change Litigation Databases http:// climatecasechart.com/non-us-case/greenpeace-nordic-assn-and-nature-youth-v-norway-ministry-ofpetroleum-and-energy/ [accessed 12 January 2021]

Prior,T.L. and Heinämäki L. (2017) 'The Rights and Role of Indigenous Women in the Climate Regime', Arctic Review on Law and Politics 8, 193-221.

Quirico, O. (2018) 'Climate Change and State Responsibility for Human Rights Violations: Causation and Imputation', Netherlands International Law Review 65(65), 185-215.

Rudyan, A.B. (2019) 'Extraterritoriality in Common Law Climate Actions: Judicial Restraint or Judicial Error', Pace Environmental Law Review 37(1), 177-209. 
Seck, S.L. (2008) 'Unilateral Home State Regulation: Imperialism or Tool for Subaltern Resistance?', Osgoode Hall Law Journal 46, 565-603.

(2011a) 'Transnational Business and Environmental Harm: A TWAIL Analysis of Home State Obligations', Trade, Law \& Development 3(1), 164-202.

(2011b) 'Conceptualizing the Home State Duty to Protect Human Rights' in Buhmann, K., Morsing, M. and Roseberry, L. (eds). Corporate Social and Human Rights Responsibilities: Global Legal and Management Perspectives, Palgrave Macmillan.

(2013a) 'Kiobel and the E-word: Reflections on Transnational Environmental Responsibility in an Interconnected World', Law at the End of the Day Blog, 5 July 2013, http://lcbackerblog.blogspot. ca/2013/07/sara-seck-on-kiobel-and-e-word.html [accessed 18 July 2021]

(2013b) ‘Transnational Judicial and Non-Judicial Remedies for Corporate Human Rights Harms: Challenges of and for Law', Windsor Yearbook of Access to Justice 31, 183-202.

(2017) 'Revisiting Transnational Corporations and Extractive Industries: Climate Justice, Feminism, and State Sovereignty', Transnational Law \& Contemporary Problems 26(2), 383-413.

(2019a) 'Moving Beyond the E-Word in the Anthropocene' in Margolies, D.S., Özsu, U., Pal, M. and Tzouvala, N. (eds). The Extraterritoriality of Law: History, Theory, Politics, Routledge.

(2019b) 'Relational Law: Re-imagining Tools for Environmental and Climate Justice', Canadian Journal of Women and the Law 31(1), 151-177.

(2021) 'A Relational Analysis of Enterprise Obligations and Carbon Majors for Climate Justice', Oñati Socio-Legal Series: Climate Justice in the Anthropocene 11(1), 254-284 https://opo.iisj.net/index.php/ osls/article/view/1217 [accessed 18 July 2021].

United Nations General (UNGA) (2019) Report of the Special Rapporteur on the issue of human rights obligations relating to the enjoyment of a safe, clean, healthy and sustainable environment: Safe Climate, A/74/161.

United Nations Framework Convention on Climate Change (UNFCCC) (n.d.a) 'Introduction of Mitigation', available at https://unfccc.int/topics/mitigation/the-big-picture/introduction-to-mitigation [accessed 12 January 2021].

(n.d.b) 'What do adaptation to climate change and resilience mean?', available at https://unfccc. $\mathrm{int} /$ topics/adaptation-and-resilience/the-big-picture/what-do-adaptation-to-climate-change-andclimate-resilience-mean [accessed 12 January 2021].

United Nations Human Rights Council (UNHRC) (2018) Report of the Special Rapporteur on the issue of human rights obligations relating to the enjoyment of a safe, clean, healthy and sustainable environment: Framework Principles, A/HRC/37/59 (annex).

United States Court of Appeals for the Ninth Circuit (n.d.) City of Oakland v. BP p.l.c., summary, Climate Change Litigation Databases, http://climatecasechart.com/case/people-state-california-v-bp-plcoakland/ [accessed 12 January 2021]

United States Supreme Court (USSC) (2013) Kiobel v. Royal Dutch Petroleum Co., 133 S. Ct. 1659. 